\title{
Quorum Sensing Inhibition Activity of Water Extract of Rhizome Herbs on Aeromonas hydrophila
}

\author{
Triyitno $^{1}$ and Murwantoko ${ }^{1 *}$ \\ ${ }^{1}$ Department of Fisheries, Faculty of Agriculture, Universitas Gadjah Mada
}

\begin{abstract}
Several bacteria have been reported to be pathogenic to fishes, and some of them were opportunistic pathogen bacteria. Quorum sensing is a widespread phenomenon in bacteria on coordinating gene expression of virulence factors of bacterial pathogens, including biofilms. The aims of this research were to confirm biofilm formation by fish pathogenic bacteria, determine activity of water extracts of medicinal rhizome herb on growth and quorum sensing inhibition of Aeromonas hydrophila. Turmeric (Curcuma longa L.), temu lawak (Curcuma xanthoriza Roxb), ginger (Zingiber officinale Roscoe), kencur (Kaempferia galanga L.) and galangal (Alpinia galangal L.) rhizomes were used in this study. The extracts were examined on their activity to affect growth and inhibition of biofilms formation by $A$. hydrophila at concentrations of 40,30, 20 and $10 \mathrm{mg} / \mathrm{ml}$. Extract of rhizome medicinal herbs did not affect the growth of $A$. hydrophila. Ginger extract at concentration of $40 \mathrm{mg} / \mathrm{ml}$ showed the highest inhibition of biofilm formation by $79.7 \%$. Turmeric extract inhibited the biofilm formation by $59.9 \%$ at concentration of $30 \mathrm{mg} / \mathrm{ml}$. Kencur extract showed the lowest biofilm inhibitory ability of $7.0 \%$. The results showed the addition of plant rhizome water extracts had anti-quorum sensing activity as evidenced by inhibition of the formation of these bacterial biofilms.
\end{abstract}

\section{Introduction}

Aquaculture is the fastest growing food production industry in the world and aquaculture development is carried out by increasing the intensification and commercialization of aquatic production. This development has consequences for the threat of disease. Disease is now a major obstacle in aquaculture, hampering economic and social development in many countries. The annual economic losses for the aquaculture industry through disease are estimated at billions of US dollars worldwide. The main pathogens affecting the aquaculture industry include: bacteria, fungi, viruses and parasites [1,2]. Given that bacteria can survive well in aquatic environments, bacterial diseases have become major impediments to aquaculture, especially when water temperature is warm [2].

At least 13 genera bacteria have been reported to be pathogenic to aquatic animals, including: Gram-negative bacteria such as Aeromonas, Edwardiella, Flavobacterium, Francisella, Photobacterium, Piscirickettsia, Pseudomonas, Tenacibaculum, Vibrio and Yersinia; and Gram-positive bacteria such as Lactococcus, Renibacterium and Streptococcus. [2]. Bacterial opportunistic pathogens are defined as microorganisms causing disease in hosts

*Corresponding author; murwantoko@ugm.ac.id 
experiencing atypical environmental stressors or having impaired immune function. In intensive aquaculture, stress factors (such as hypoxia, abnormal $\mathrm{pH}$, and high population density) generate an optimal setting for such pathogens to thrive. Aeromonas, Flavobacterium, and Vibrio are important major opportunist in aquaculture [3]. Aeromonas hydrophila is important pathogenic bacterium which caused significant loss especially in freshwater aquaculture, and has been confirmed in Indonesia [4,5].

Bacteria behave as single cellular organisms at low cell densities; however, they may shift their behavior to 'multicellular' type by sensing that their population density has reached a threshold level. At this stage, they communicate through small signaling molecules, which enable them to express genes for different phenotypes, especially those responsible for their virulent behavior. This quorum sensing regulates gene expression in response to fluctuations in cell-population density. Quorum sensing (QS) bacteria produce and release chemical signal molecules called autoinducers that increase in concentration as a function of cell density. This mechanism may coordinate gene expression of virulence factors of bacterial pathogens, including biofilms [6].

The process of QS can be disrupted by different mechanisms: reducing the activity of AHL cognate receptor protein or AHL synthase, inhibiting the production of QS signal molecules degradation of the AHL, and mimicking the signal molecules primarily by using synthetic compounds as analogues of signal molecules. The process of quorum sensing can be disrupted by different mechanisms, including inhibiting the production of quorum sensing signal molecules. The natural quorum sensing inhibitors can be obtained from prokaryotic, animal, plant, marine organism, fungus [6].

Many herbs have been used as traditional medicine, including rhizomes such as ginger, temu lawak, galangar, turmeric, and kencur. Ginger (Zingiber officinale Roscoe) contained phenols, flavonoids, terpenoids and essential oils [7]. Phytochemical analysis of temu lawak (Curcuma xanthoriza Roxb) showed that this contained alkaloids, flavonoids, phenolics, triterpennoids, glycosides, tannins, saponins and steroids [8]. Turmeric (Curcuma longa L.) contained high levels of polyphenols, flavonoids, tannins and vitamin C [9]. Galangal (Alpinia galanga L.) contains alkaloids, saponins, flavonoids, triterpenoids, and quinones [10]. Kencur (Kaempferia galanga L.) contained alkaloids, flavonoids, polyphenols, tannins, monoterpenes, sesquiterpenes, steroids [11].

Study on the usage on water extracts of herb on the inhibition of biofilm production has been carried out. Soković et al. used a water extract from the Agaricus blazei mushroom to be tested on virulence factors and Pseudomonas aeruginosa biofilm formation [12]. Adonizio et al. conducted a test of water extract from six plants, on virulence factors of $P$. aeruginosa and QS systems on several organisms [13]. In this study we evaluate the activity of water extracts from temu lawak ginger, galangal, kencur and turmeric on growth and quorum sensing inhibition of Aeromonas hydrophila

\section{Methods}

\section{a. Bacterial culture}

The fish pathogenic bacteria as Proteus mirabilis CTA H2, Aeromonas hydrophila CTA K2, Aeromonas veronii KOA 5.1, Aeromonas aquariorum KOC 2.2, Aeromonas veronii PT11.G2.Tc, Klebsiella pneumoniae PT1.L.T, Aeromonas sharmana PT5.L3.T, Photobacterium damselae SB 22, Vibrio harveii SB 25 dan Vibrio azureus JP 01 were collections of Laboratory of Fish Health and Environment, Department of Fisheries, UGM. Those bacteria are cultured with Tryptic Soy Broth (TSB) media an incubated at $30^{\circ} \mathrm{C}$. 


\section{b. Rhizome extraction}

The turmeric/kunir (Curcuma longa L.), temu lawak (Curcuma xanthoriza Roxb), ginger/jahe (Zingiber officinale Roscoe), kencur (Kaempferia galanga L.) and galangal/ lengkuas (Alpinia galangal L.) rhizomes were collected from traditional market in Yogyakarta. The air dry of rhizomes were proceeded on hot water extract based on Adonizio et al. [13]. Dry rhizomes are blended until they become powder. Extraction was done by making a $10 \%$ suspension of powder in the water followed by boiling for five minutes. The suspension was centrifuged at a speed of $10.000 \mathrm{~g}$ for five minutes, then the supernatant was filtered using a $0.2 \mu \mathrm{m}$ filter

\section{c. Biofilm evaluation}

Evaluation of the ability of bacteria to produce biofilms was evaluated by staining with Congo red and crystal violets. The method for biofilm staining with Congo red was modified from Allison \& Sutherland (1984). Sterile glass slides were immersed in fish pathogenic bacterial culture with TSB medium in flash and incubated at $30{ }^{\circ} \mathrm{C}$ for 24 hours. Then the slides were taken out and fixed by heating. Slides were stained with mixture Congo red and $10 \%$ Tween $80(1: 1)$ solution for 15 minutes followed by staining with $10 \%$ Ziehl carbol fuchsin for 6 minutes.

Evaluation of biofilm formation with Crystal violet follow the method of Microtiter-Plate Biofilm Assay [14]. The bacteria were cultured on TSB medium in the microplate at $30^{\circ} \mathrm{C}$ for 24 hours. The wells were fixed with methanol for 15 minutes and stained with $2 \%$ crystal violet for five minutes. Microplate was washed with PBS and added $200 \mu \mathrm{l}$ of glacial acetic acid 33\%. Qualitative observation of the level of purple density by scoring the + value for the color formed, ++ to form a solid color and - for no color to form. For quantitative observations, the solutions were measured on the adsorption value with a spectrophotometer at a wavelength of $570 \mathrm{~nm}$.

\section{d. Effect of extracts of rhizomes on growth and biofilm formation}

The experiment to determine the effect of extracts of rhizomes on growth and biofilm formation was carried out using a completely randomized design (CRD) consisting of 6 treatments with 3 replications. The treatments were the administration rhizome extracts of turmeric (kunir), temu lawak, ginger (jahe), galingale (kencur), galangal (lengkuas) and control. The extract dose is given in the amount of 40,30,20 and $10 \mathrm{mg} / \mathrm{ml}$. The high density of $A$. hydrophila bacteria was cultured on TSB medium on a flat-bottom microplate in incubator $30^{\circ} \mathrm{C}$ for 24 hours. The absorbance of planktonic bacteria was measured using spectrophotometer at a wavelength of $600 \mathrm{~nm}$, and the bacterial densities were estimated using standard curve of absorbance and density of life bacteria during exponential growth stage. Quantitative biofilm measurements were evaluated by staining with crystal violet and spectrophotometer a wavelength of $570 \mathrm{~nm}$ [14]. The percentage inhibition of biofilm formation follows equation of Vikram et al. [15].

\section{Result}

Bacteria formed biofilms as indicated by purplish blue from Crystal violet dyes which were then dissolved with $33 \%$ acetic acid. Biofilm formation in glass slide was visualized by staining and observed using a light microscope. Biofilm looks pink attached on the surface of glass slide due to Congo red stain. Bacterial cells look purplish after absorbing the purple 
color from Ziehl carbol fuchsin. The production of biofilm by bacteria was shown in Table 1. Almost all of the pathogenic fish bacteria are produced biofilm. The production of biofilm by Aeromonas hydrophila CTA K2 was clearly observed both by crystal violet and congored staining. As A. hydrophila has been widely known as freshwater fish pathogen, we used this A. hydrophila for the study.

Tabel 1. Biofilm production by bacteria

\begin{tabular}{|l|l|c|c|c|}
\hline \multirow{2}{*}{ Kode } & \multirow{2}{*}{ Isolat } & \multicolumn{2}{|c|}{ Staining } & \multirow{2}{*}{ Biofilm } \\
\cline { 3 - 4 } & & $\begin{array}{r}\text { Crystal } \\
\text { violet }\end{array}$ & Congored & \\
\hline SB 22 & Photobacterium damselae & + & + & ++ \\
\hline SB 25 & Vibrio harveii & + & + & ++ \\
\hline KOA 5.1 & Aeromonas veronii & + & + & ++ \\
\hline CTA K2 & Aeromonas hydrophila & + & + & ++ \\
\hline JP 01 & Vibrio azureus & + & + & ++ \\
\hline PT11.G2.Tc & Aeromonas veronii & + & + & ++ \\
\hline PT5.L3.T & Aeromonas sharmana & - & + & + \\
\hline PT1.L.T & Klebsiella pneumoniae & + & + & ++ \\
\hline KOC 2.2 & Aeromonas aquariorum & - & + & + \\
\hline CTA H2 & Proteus mirabilis & ++ & + & +++ \\
\hline
\end{tabular}

* + indicate the level of biofilm production

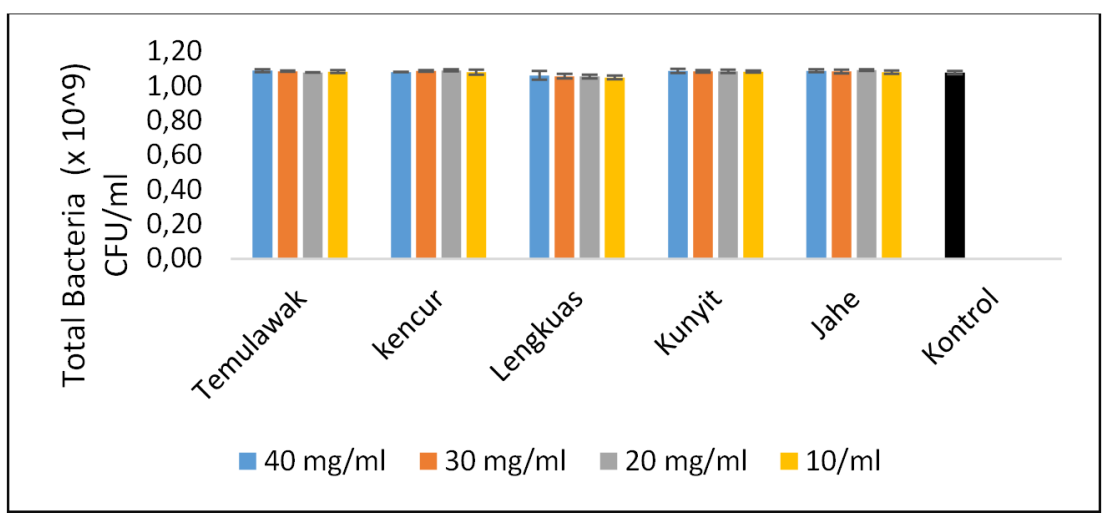

Fig 1. The density of bacteria in the present of various dose of rhizome extracts

The initial bacterial culture that was inoculated into the microplate was $10^{8} \mathrm{CFU} / \mathrm{ml}$, after being cultured for 24 hours the total bacteria rose to $10^{9} \mathrm{CFU} / \mathrm{ml}$. The administration of galangal extract yielded the lowest density as $1.05 \times 109 \mathrm{CFU} / \mathrm{ml}$. The highest density was found in the administration of turmeric and ginger, which was $1.09 \times 10^{9} \mathrm{CFU} / \mathrm{ml}$. However density of bacteria among the treatments of extract were not significantly different from the 
control $(\mathrm{P}<0.05)$. This indicates that the addition of extracts does not affect bacterial growth. The density of bacteria in the present of rhizome extract is presented in Figure 1.

Statistical analysis of two-way ANOVA showed significant differences on inhibition of biofilm formation among type of rhizome and concentration $(P<0.05)$. The addition of kencur extract did not provide significant results in inhibiting biofilm formation. The addition of temu lawak, ginger, galangal and turmeric extracts inhibited biofilm formation (Table 2).

Tabel 2. Inhibition activity of water rhizomes extracts on biofilm production by $A$. hydrophila

\begin{tabular}{|c|c|c|c|}
\hline Treatment & $\begin{array}{c}\text { Concentration } \\
(\mathrm{mg} / \mathrm{ml})\end{array}$ & $\begin{array}{l}\text { Optical } \\
\text { Density }\end{array}$ & $\begin{array}{c}\text { Biofilm Inhibition Index } \\
(\%)\end{array}$ \\
\hline Control & & $0.454 \pm 0.01$ & $00.0 \pm 1.6^{\mathrm{a}}$ \\
\hline \multirow[t]{4}{*}{ Temulawak } & 40 & $0.306 \pm 0.01$ & $32.7 \pm 1.8^{\mathrm{e}}$ \\
\hline & 30 & $0.328 \pm 0.06$ & $27.7 \pm 13.8^{\mathrm{de}}$ \\
\hline & 20 & $0.332 \pm 0.02$ & $27.0 \pm 4.3^{\mathrm{de}}$ \\
\hline & 10 & $0.333 \pm 0.02$ & $26.8 \pm 4.2^{\mathrm{de}}$ \\
\hline \multirow[t]{4}{*}{ Kencur } & 40 & $0.429 \pm 0.03$ & $5.6 \pm 6.3^{\mathrm{ab}}$ \\
\hline & 30 & $0.425 \pm 0.02$ & $6.4 \pm 4.1^{\mathrm{ab}}$ \\
\hline & 20 & $0.432 \pm 0.05$ & $4.8 \pm 12.1^{\mathrm{ab}}$ \\
\hline & 10 & $0.422 \pm 0.02$ & $7.0 \pm 4.0 \mathrm{abc}$ \\
\hline \multirow[t]{4}{*}{ Lengkuas } & 40 & $0.345 \pm 0.02$ & $24.1 \pm 3.7^{\text {cde }}$ \\
\hline & 30 & $0.362 \pm 0.03$ & $20.2 \pm 6.4$ bcde \\
\hline & 20 & $0.392 \pm 0.05$ & $13.7 \pm 10.7 \mathrm{abcd}$ \\
\hline & 10 & $0.462 \pm 0.02$ & $-1.6 \pm 3.7^{\mathrm{a}}$ \\
\hline \multirow[t]{4}{*}{ Kunyit } & 40 & $0.187 \pm 0.01$ & $58.8 \pm 1.8^{\mathrm{f}}$ \\
\hline & 30 & $0.182 \pm 0.04$ & $59.9 \pm 8.5^{f}$ \\
\hline & 20 & $0.203 \pm 0.01$ & $55.4 \pm 2.0^{\mathrm{f}}$ \\
\hline & 10 & $0.329 \pm 0.01$ & $27.5 \pm 1.8^{\mathrm{de}}$ \\
\hline \multirow[t]{4}{*}{ Jahe } & 40 & $0.092 \pm 0.00$ & $79.7 \pm 1.1^{\mathrm{g}}$ \\
\hline & 30 & $0.133 \pm 0.04$ & $70.8 \pm 8.9^{\mathrm{fg}}$ \\
\hline & 20 & $0.142 \pm 0.01$ & $68.7 \pm 1.8^{\mathrm{fg}}$ \\
\hline & 10 & $0.169 \pm 0.01$ & $62.7 \pm 2.3^{\mathrm{fg}}$ \\
\hline
\end{tabular}

*values followed by with same superscript indicated not significantly different $(\mathrm{P}>0,05)$

The types of rhizome and their concentration showed significant inhibition on biofilm formation $(\mathrm{P}<0.05)$. Addition of temu lawak, ginger, galangal and turmeric extracts were able to inhibit biofilm formation, whereas kencur extract did not significantly inhibit biofilm formation. Ginger has strongest inhibition activity, which a concentration of $40 \mathrm{mg} / \mathrm{ml}$ showed inhibition biofilm formation of $79.7 \%$. Ginger extract at a concentration of $30 \mathrm{mg} / \mathrm{ml}$, $20 \mathrm{mg} / \mathrm{ml}$ and $10 \mathrm{mg} / \mathrm{ml}$ inhibited biofilm formation $70.8 \%, 68.7 \%$ and $62.7 \%$ respectively. The second strongest rhizome was turmeric had the highest inhibitory ability of $58.8 \%$, $59.9 \%$ and $55.4 \%$ when applied at a concentration of 40.30 and $20 \mathrm{mg} / \mathrm{ml}$. Temu lawak only 
has weak inhibition ability only reached $32.7 \%$ at when applied at concentration of $40 \mathrm{mg} / \mathrm{ml}$. While kencur didn't have inhibition activity (Figure 2).

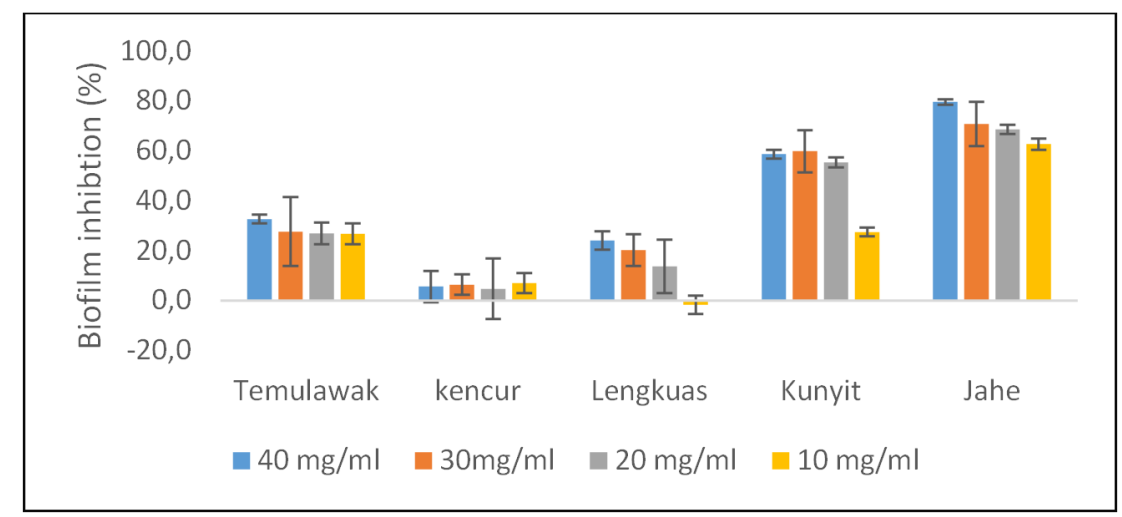

Fig 2. Inhibition of $A$. hydrophila biofilm production by water rhizome extract at different concentration.

\section{Discussion}

An integrated approach that considers the pathogen, the host and the environment will be the most effective method in the long-term to improve aquatic animal health. From the pathogen perspective, alternative methods in integrated management include: using antimicrobial compounds, using pathogen-specific bacteriophages; using short-chain fatty acids and polyhydroxy alkenoates to inhibit the growth of bacteria; and using compounds to inhibit virulence gene expression or interrupt the signal transduction pathways of the pathogens [2]. This study was to address on the last approach, screening on the compounds to inhibit virulence gene expression or interrupt the signal transduction pathways of the pathogens

This quorum sensing regulates gene expression in response to fluctuations in cellpopulation density and may coordinate gene expression of virulence factors of bacterial pathogens, including biofilms [6]. In this study we used biofilm as a parameter of quorum sensing. These biofilms are easily observed and also have an important role in pathogenesis and bacterial resistance to antibiotics. Bacteria in biofilms behave differently from planktonic bacteria, especially in terms of their response to antibiotics. Bacteria that have formed biofilms are very resistant to antibiotics. By forming biofilms, the value of minimal inhibitory concentration (MIC) and minimal bactericidal concentration (MBC) antibiotics increased up to 100-1000 times. The longer the life of the biofilm cell, the higher its resistance to antibacterial and disinfectant because of the formation of several layers of biofilm (multilayers) cells on the substrate [17].

Ginger, temu lawak, galangar, turmeric, kencur rhizome have been analyzed contained many substances such as Phenols, polyphenols, flavonoids, terpenoids, monoterpenes triterpennoids sesquiterpenes, glycosides, tannins, saponins, steroids, vitamin C, quinones or essential oils $[7,8,9,10,11]$. Several substances are polar substance which can be extracted with water. Tanvir et al. succeeded in getting polyphenols, flavonoids, tannins, and ascorbic acid content from turmeric water extract [9]. Iswantini et al. obtained galangal and kencur water extracts containing alkaloids, saponins, flavonoids, and quinones [10].

Studies on the use of water extracts has been carried out for biofilm inhibition tests. Soković et al. used a water extract from the Agaricus blazei mushroom did not kill $P$. aeruginosa or inhibit its growth, but showed a statistically significant reduction of virulence factor expression and biofilm formation [14]. In this study, it was found that similar results 
showed that water extract extracted from ginger, ginger, galangal, kencur and turmeric did not have the ability to inhibit bacterial growth. Taro extract, ginger, galangal and turmeric are known to have the ability to inhibit biofilm formation. Turmeric also has been reported able to inhibit virulence genes expression on P. aeruginosa [18]. Tannic acid-treated $A$. hydrophila showed a considerable reduction in violacein production, blood hemolysis activity, the pattern of swarming motility and biofilm formation [16].

Quorum sensing have been known regulates expression of various virulence factor genes from pathogenic bacteria. In this study only evaluating quorum sensing using biofilms as one of virulence factor. Thus, for the future, it can be studied any virulence factors that are regulated and can be controlled by providing quorum sensing inhibitors. In this study, the types of active ingredients extracted on materials that showed quorum sensing inhibitor activity were not analyzed. So that in the future it is necessary to see the type of active compounds that have this inhibitor activity

\section{Conclusion and Suggestion}

Water extracts of temu lawak, ginger, galangal, kencur and turmeric do not have the ability to inhibit bacterial growth. Temu lawak, ginger, galangal and turmeric water extracts have the ability to inhibit biofilm formation.

For future research, we need to look at the types of virulence factors that can be inhibited by the Quorum sensing inhibitor, and need to identify the types of active compounds that have Quorum sensing inhibitor activity

\section{Acknowledgement}

This study was funded by Hibah Fakultas Pertanian UGM No 2346/PN/TU/2018

\section{References}

1. MG Bondad-Reantaso, RP Subasinghe, JR Arthur, K. Ogawa, S. Chinabut, R. Adlard, Z. Tan and M. Shariff. Disease and health management in Asian aquaculture. Vet Parasitol. 32: 249-72 (2005)

2. J.W Pridgeon and P.H. Klesius. Major Bacterial Diseases in Aquaculture and Their Vaccine Development. CAB. Reviews 7 No 048 (2012)

3. N. Derome, J. Gauthier, S. Boutin, M, Llewellyn. Bacterial Opportunistic Pathogens of Fish. In book: The Rasputin Effect: When Commensals and Symbionts Become Parasitic. Christon J. Hurst(Ed). Springer (2016)

4. Murwantoko, Rozi, I. Istiqomah, K.H. Nitimulyo. Isolasi, Karakterisasi, dan Patogenitas Bakteri Penyebab Penyakit pada Gurami (Osphronemus goramy) di Kabupaten Bantul. Jurnal Perikanan 15: 83-90 (2013)

5. S. Rejeki, Murwantoko and Triyanto. Isolation and Identification of Aeromonas spp. from Diseased African Catfish (Clarias sp.) in Ngawi Regency. Jurnal Perikanan 18 : 55-60 (2016)

6. V.C. Kalia. Quorum sensing inhibitors: An overview. Biotecnology Advances 31: 224245 (2013)

7. C. Winarti and N. Nurdjanah. Peluang tanaman rempah dan obat sebagai sumber pangan fungsional. Jurnal Litbang Pertanian. 24(2):47-55 (2005) 
8. E. Hayani, Analisis Kandungan Kimia Rimpang Temulawak. Teknis Nasional Tenaga Fungsional Pertanian. Pusat Penelitian Dan Pengembangan Peternakan, 309-312 (2006)

9. E. M. Tanvir, M. Hossen, M. Hossain, R. Afroz, S.H. Gan, M. Khalil, dan N. Karim. Antioxidant properties of popular turmeric (Curcuma longa) varieties from Bangladesh. Journal of Food Quality. 2017:1-8 (2017)

10. D. Iswantini, L.K. Darusman, dan A. Fitriyani. Uji in vitro ekstrak air dan etanol dari buah asam gelugur, rimpang lengkuas, dan kencur sebagai inhibitor aktivitas lipase pankreas. Jurnal Sains dan Teknologi Indonesia, 12(1): 15-20 (2010)

11. A.N. Hasanah, F. Nazaruddin, E. Febrina, dan A. Zuhrotun. Analisis Kandungan Minyak Atsiri dan Uji Aktivitas Antiinflamasi Ekstrak Rimpang Kencur (Kaempferia galanga L.). Jurnal Matematika \& Sains. 16(3): 147-153 (2011)

12. M. Soković, A. Ćirić, J. Glamočlija, M. Nikolić, dan L.J. van Griensven. Agaricus blazei hot water extract shows anti quorum sensing activity in the nosocomial human pathogen Pseudomonas aeruginosa. Molecules. 19 (4):4189-4199 (2014)

13. A. L. Adonizio, K. Downum, B. C. Bennett, and K. Mathee. Anti-quorum sensing activity of medicinal plants in southern Florida. J. Ethnopharmacol. 103:427-435 (2006)

14. S. Stepanović, D. Vuković, I. Dakić, B. Savić, dan M.S. Vlahović. A modified microtiter-plate test for quantification of staphylococcal biofilm formation. Journal of microbiological methods. 40:175-179 (2000)

15. A. Vikram, G.K. Jayaprakasha, P.R. Jesudhasan, S.D. Pillai, dan B.S. Patil. Suppression of bacterial cell-cell signaling, biofilm formation and type III secretion system by citrus flavonoids. J Appl Microbiol. 109:515-27 (2010)

16. B. Patel, S. Kumari, R. Banerjee, M. Samanta and S. Das. Disruption of the quorum sensing regulated pathogenic traits of the biofilm-forming fish pathogen Aeromonas hydrophila by tannic acid, a potent quorum quencher. Biofouling 33 : 580-590 (2017)

17. P.L. Chen, C.J. Wu, C.S. Chen, P.J. Tsai, H.J. Tang, dan W.C.Ko. 2014. A comparative study of clinical Aeromonas dhakensis and Aeromonas hydrophila isolates in southern Taiwan: A. dhakensis is more predominant and virulent. Clinical Microbiology and Infection, 20(7): O428-O434.

18. T. Rudrappa and H.P. Bais. 2008. Curcumin, a known phenolic from Curcuma longa, attenuates the virulence of Pseudomonas aeruginosa PAO1 in whole plant and animal pathogenicity models. J Agric Food Chem. 56:1955-62. 